of this discipline, but of academic careers in general. When the material rewards, in terms of salary and security, are matched against the effort, it may hardly seem worth it in any rational sense.

Yet there are some important compensations. In most cases, this career offers the prospect of being able to define one's own objectives and control the pace and content of one's labor. It offers the many rewards of teaching-making a difference in the lives of others, starting students on their own quest for knowledge, contributing to the betterment of community and so on. It often includes the opportunity to participate in work at the frontiers of knowledge about a critical dimension of human life. It almost always provides a lifetime's worth of intellectual challenges, often in company with help- ful and exciting people who encourage one to keep trying to meet those challenges. It can, in short, make life interesting. And for all of those that fall by the wayside, there are many others who make it through successfully.

Further, while it shares the liabilities of an academic life, a scholarly career in political science offers the same compensations. For many, this includes a measure of modest financial security with tenure. More importantly for most, whether in research or teaching, it offers the excitement of making a living by one's wits, of shaping events (occasionally) and minds (often) on the strength of pure intellectual energy.

For some, such compensations are enough rationally to offset the risks of failure this career entails. For others, there is no question of

\title{
Recruiting Minority Students for Academic Careers: The Role of Graduate Student and Faculty Mentors
}

\author{
Carlos E. Juárez, University of California, Los Angeles
}

In a recent issue of $P S$ (23: 229-232), Catherine Rudder called attention to various APSA projects designed to address the "pipeline" problem - the need to recruit minorities into graduate school and into the political science professoriate. With the anticipated shortage of faculty in the coming decade, there is a window of opportunity to bring more minority group members into the profession. The task of recruiting minority students for academic careers requires a concerted effort not only on the part of professional associations like the APSA (Garcia and Smith 1991) but more directly of faculty and graduate student mentors.

At the University of California, Los Angeles (UCLA), an innovative graduate mentorship program was initiated in the College of Letters \& Sciences during the 1990-91 academic year. The new Graduate Mentor Program (GMP) is designed to increase the number of faculty of color within educational institutions by encouraging talented minority students to consider academic careers. Often when these students pursue advanced degrees, they choose professional schools to prepare for careers in law, medicine, or business. Masters and Ph.D. programs in traditional academic disciplines are less likely to be considered. A GMP survey revealed that among the reasons for this was lack of knowledge about graduate school, the graduate application process, and the long-term rewards of graduate education.

The GMP program is an important step in the pipeline for academic careers as it strives to educate students about graduate school options. Experienced minority graduate students from different academic disciplines coordinate a wide range of support services for minority and low income students.

The need for a graduate mentor program arose out of recognition that a growing number of undergraduate minority students represent a significant pool of potential academic scholars. Figures from the Office of Academic Planning at UCLA reveal that in 1980 , the choice, since the alternatives are so infinitely less attractive as to be unthinkable while any hope of success remains. It is in the hope of saving these last committed aspirants that I have set these lessons down.

\section{Note}

*I am very grateful for assistance from several people in commenting on various drafts of this article. They include Paula Sage, Bob Heineman, Ted Bluhm, Mike Schatzberg, and Booth Fowler.

\section{About the Author \\ John D. Harman is an associate professor of political science at St. John Fisher College. A past president of the New York State Polit- ical Science Association, he is the author of several articles in political theory.}

freshman class at UCLA was $67 \%$ white and $33 \%$ ethnic minority. A decade later, the 1990 freshman class was the reverse: $36 \%$ white and $64 \%$ minority. Students of color now account for more than half of all UCLA undergraduates, making the campus, along with Berkeley, the most diverse research university in the nation. Yet despite this demographic change at the undergraduate level, graduate programs at UCLA and elsewhere remain provinces of white privilege.

\section{Graduate Student Mentors}

The GMP's Graduate Student Mentors provide individualized counseling and advice on all aspects of graduate school preparation. Throughout the year, various workshops and seminars are organized on topics relevant to graduate studies. These include workshops to explain the graduate school application process and familiarize students with options for financing graduate educa- 
tion, as well as preparation seminars for the GRE exams.

As students of color themselves, Graduate Student Mentors serve as positive role models and are seen by undergraduates as more "in tune" with their concerns and viewpoints. Since minority students are often the first in their families to attend a university, issues like family, finances, and racism take on an added dimension as students of color bring particular experiences and perspectives to higher education.

Graduate Student Mentors also facilitate a linkage between undergraduate students and faculty. Through informal roundtable discussions, students are given the opportunity to interact directly with faculty and graduate students, thus becoming exposed to the rigors and rewards of academic research. Undergraduates are strongly encouraged to participate in student research programs like the APSA's Ralph Bunche Summer Institute and similar programs nationwide.

\section{The Role of Faculty Mentors}

An essential part of any success in recruiting more minorities into doctoral programs is the role and con- tribution of faculty. Faculty members can have an important impact on the intellectual development of undergraduates by exposing them to academic research and encouraging them to pursue graduate studies. Quite often it is the influence of a particular faculty or high school teacher that sparks an interest in scholarly pursuits.

The GMP faculty-student roundtables bring together minority undergraduates and faculty members to discuss graduate school options and academic careers. The opportunity for students to meet with faculty outside of the classroom, in an informal setting, allows them to develop a better understanding of graduate education and academic research. It is important for faculty members to recognize their vital role as mentors and encourage minority students to enroll in directed research projects or work for them as research assistants.

The faculties of tomorrow will need to reflect current demographic realities in American society. As DePalma (1991) points out, by the year 2000, a third of all elementary and high school students are expected to come from minority groups, making this pool of students even more important to the future of postsecondary education. The need to recruit minorities into the profession must become a top priority in higher education. The Graduate Mentor Program at UCLA, and similar programs nationwide, is a step in the right direction.

\section{References}

DePalma, Anthony, 1991. "Higher Education Feels the Heat." New York Times, 2 June 1991, IV-1.

Garcia, John A., and Robert C. Smith. 1990. "Meeting the National Need for Minority Scholars and Scholarship: What Professional Associations Might Do." PS: Political Science \& Politics 23: 62-63.

Rudder, Catherine. 1990. "APSA Minority Programs Addressing the Pipeline Problem." PS: Political Science \& Politics 23: 229-232.

UCLA Ethnic Enrollment Report, October 24, 1990. Office of Academic Planning and Budget.

\footnotetext{
About the Author

Carlos E. Juárez is a Ph.D. candidate at UCLA where he is completing his dissertation on the politics of foreign trade in Colombia. He worked as a graduate mentor in political science for the GMP pilot program. During the 1991-92 academic year, he will be a visiting scholar at the Universidad de los Andes in Bogotá, Colombia.
} 